\title{
ハンドル形電動車いすによる施設利用上の問題点とその改善方策について 一電動車いすユーザーに対応する生活環境のあり方に関する研究 その 2 - METHODS TO IMPROVE ENVIRONMENT OF COMMUNITY FACILITIES FOR HANDLE TYPE ELECTRIC WHEELCHAIR USERS' BEHAVIOR \\ - Study on living environment for electric wheelchair users Part 2-
}

中島 佐智子*, 柏 原士 郎**, 横田 隆司***, 吉 村 英 祐****, 飯 田 匡*****

Sachiko NAKASHIMA, Shiro KASHIHARA, Takashi YOKOTA, Hidemasa YOSHIMURA and Tadasu IIDA

\begin{abstract}
The aim of this study is to clarify the methods to improve the built environment of community facilities for handle type electric wheelchair users by the interview, measurement of the size, and behavioral observation. As a result of this study, the following has been clarified.

1) Electric wheelchair make users' outdoor lives more active, and their behavioral range wider. 2) Usability of community facilities by handle type electric wheelchair users depends on both their personal factors and environmental factors. 3) Therefore, the built environment of community facilities for them should be changed according to scale and kind of the facilities.
\end{abstract}

Keywords: handle type electric wheelchairs, investigation, barrier-free design ハンドル形電動車いす，実態調查，バリアフリーデザイン

1 はじめに

歩行が困難な障害者や高齢者にとって、様々な移動機器注 1 )を使 用して地域で普通に生活していくことは基本的な権利であり、人 間らしい生活を支える基盤である。我が国ではバリアフリー環境 の向上のため、各自治体の福祉のまちづくり条例、ハートビル法、 交通バリアフリー法等が整備され、車い寸対応トイレやスロープ、 エレベータ等の設置箇所増加により、移動機器ユーザーの生活環 境は大きく改善されてきている。これらのバリアフリ一環境をよ り良質な社会資源として活用していくためには、それらが実際に どのような使われ方をしているか（使われない場合を含め）とい う情報を収集し、改善点を明確にしていく必要がある。 本研究は、比較的新しい移動機器である電動車いす注 2)に対する 地域施設注 3 ) 整備のための基礎資料を得ることを目的としている。 前報文2)においては、標準形電動車い寸ユーザーによる施設利用状 況を主な対象とし、その問題点を報告した。本論文では、ハンド ル形電動車いすに関する調查について述べる。

\section{2 研究対象及び方法}

J I S 規格が適用される電動車いすには、一般的に「電動車いす」 として捉えられている標準形等 (ジョイスティックと呼ばれるレバ 一で操作するものが多い）と、「電動カート小、「シニアカー」等と 呼称されているハンドル形の二つのタイプが含まれている。注4)(図 1)。この両者は外形的な相違の他、方向転換する際の駆動方法も相
違している注5)。

既往の研究によると、溝端、北川文3)による全国アンケートの結 果では、ハンドル形電動車いすのユーザーは、60 歳代以上の高年齢 層が 9 割以上を占め、歩行能力に関しては、「不自由がない $10 \%$ 、 「長い距離の歩行が困難」57\%となっている。両者を合わせた $67 \%$ 、 つまり約 $2 / 3$ のユーザーが、短距離の歩行であれば困難はないと見 られるが、これは他の車いす（標準形等の電動車いすや手動車いす。 以下、同様）と相違する点である。本研究の対象とする電動車いす のユーザー層の相違を、歩行困難度と年齢の二軸で表わした概念図 を図 1 に示す。

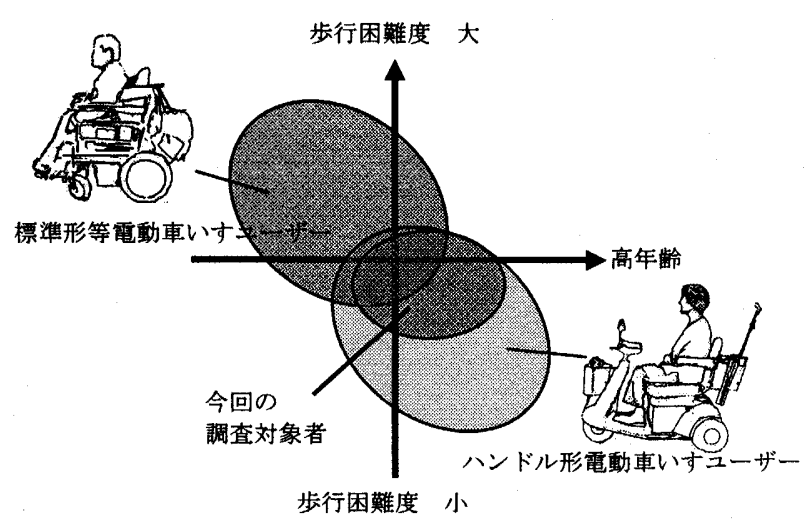

図 1 骤隼形等電動車いすとハンドル形電勳車いすのユーザー層概念図

\footnotetext{
本報は文1)を加筆, 修正したものである。

$*$ 大阪大学大学院工学研究科 博士後期課程 - 修士 (工学)

** 武庫川女子大学 教授. 工博

*** 大阪大学大学院工学研究科 教授 - 博士 (工学)

**** 大阪大学大学院工学研究科 助教授・博士 (工学)

***** 大阪大学大学院工学研究科 助手 $\cdot$ 博士 (工学)
}

Graduate Student, Graduate School of Eng., Osaka Univ., M. Eng.

Prof., Mukogawa Women's Univ., Dr. Eng.

Prof., Graduate School of Eng., Osaka Univ., Dr. Eng.

Assoc. Prof., Graduate School of Eng., Osaka Univ., Dr. Eng.

Research Assoc., Graduate School of Eng., Osaka Univ., Dr. Eng. 
前報文2)における調査結果では、現在バリアフリー設計の基準と なっている手動車いすと標準形等電動車いすでは、機器寸法、ユー ザーの体の寸法、回転性能等が相違しているため、電動車いすユー ザーが、車いす対応を念頭において設計されている設備を使いにく い、るいは使えないという事例があることが判明した。ハンドル 形電動車いすの場合は、他の車いすと異なる機器形状、動作性を考 虑すると、それらと異なる使用状況やニーズがあると考えられる。 本報では、ハンドル形電動車いすの使用事例について、ヒアリング 調査（外形寸法等の実測調查を含む）及び行動観察調查を実施した 結果を報告する。

\section{3 調查概要}

3. 1 ヒアリング調查（2003 年 7 月〜2004 年 5 月）

ハンドル形電動車いすユーザー12 人に対して、その使用状況及 び地域施設の利用状況に関するヒアリングを行い、同時に使用す るハンドル形電動車いすの外形寸法、回転半径を実測した。

調査対象者の属性及びハンドル形電動車い寸の選択理由を表 1 に示す。また、主要なヒアリング項目は表 2 の通りである。

\section{2 行動観察調查（2003 年 7 月 2004 年 9 月）}

ハンドル形電動車い寸ユーザーの行動を観察し、移動の手段と経 路、上下移動に使用したエレベータやスロープなどを記録すると
共に、写真（一部ビデオ）記録及び何らかの問題が観察された時 点での建筑部位の寸法等の計測を行った。対象者はヒアリングを 行ったハンドル形電動車い寸ューザーのうち 10 人であり、 1 人に つき $1 \sim 6$ 回、計 16 日行った。調査記録の概要は、店舗等の建築 物、トイレやエレベータ等の設備、及び交通機関や道路について の、ハンドル形電動車いすューザーによる利用状況である（表 3 ）。

\section{4 調査結果と考察}

4.1 調査対象者の属性（身体状況、年跉）等について

前報文2)における電動車いすの使用実態調查では、標準形等電動 車いすユーザーの身体状況として、全身性の肢体不自由者が多く、 短距離の歩行（伝い歩き、杖等使用を含む。以下同様）が可能であ る人は、ヒアリング対象者 30 人中 5 人であったが、今回のハンド ル形電動車いす調查対象者は、反対に、歩行がまったく不可能であ る人は 12 人中 2 人（うち 1 人は調查時点には標準形電動車いすを 使用）であり、他の 9 人は可能である。しかし、12 人全てが障害者 手帳を所持し、短距離であっても歩行するには何らかの困難を伴う。 また、調査対象者の年跲構成は、30 歳代 1 人、40 歳代 3 人、50 歳代 2 人、60 歳代 4 人、7 0 歳代 2 人であり、図 1 に示したように、 ハンドル形電動車いすューザー層全体の中では、相対的に年齢が低 く、歩行困難度が大きいところに属している。

表 1 調套対象者の属性と機器の選択理由

\begin{tabular}{|c|c|c|c|c|c|c|c|}
\hline No. & 性別 & 年齢 & 「障害」 & 歩行に関するAD L & ハンドル形電動車いすの入手方法 & ハンドル形電動車いすの選択理由 & 使用機種 \\
\hline 1 & 男性 & 45 & 脑性麻㾝 & 短距離步行可 & 補装具制度による給付 & ジョイスティックは操作しづらい。 & $N$ (A 社) \\
\hline 2 & 男性 & 75 & 左半身麻㾝 & 短距離步行可 & 自費購入 & 買物に便利。安定性がある。 & $N(\mathrm{~K}$ 社) \\
\hline 3 & 男性 & 64 & ポリオ & 短距離歩行可 & 自費購入 & 荷物が運べる。 & $S$ (S 社) \\
\hline 4 & 男性 & 61 & 下肢障害 & 短距離歩行可 & 自費購入 & 車いすらしくないところがよい。 & $\mathrm{Y}(\mathrm{C}$ 社) \\
\hline 5 & 女性 & 49 & 脳性森㾝 & 短距離步行可 & 補装具制度による給付 & ジョイスティックの操作が怖い。 & $N$ (K 社) \\
\hline 6 & 男性 & 41 & 不明（肢体不自由） & 步行不可 & 補装具制度による給付 & ジョイスティックは操作しづらい。 & $S$ (S 社) \\
\hline 7 & 女性 & 50 & 関節リウマチ & 短距離歩行可 & 補装具制度による給付 & ジョイスティックは操作しづらい。 & $S$ (S 社) \\
\hline 8 & 男性 & 36 & 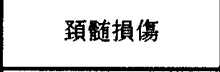 & 歩行不可 & 不明 & $\begin{array}{l}\text { 最初に乗ったのがハンドル形雨動車 } \\
\text { いすだった。現在は標準形を使用。 }\end{array}$ & 不明 ( $\mathrm{H}$ 社) \\
\hline 9 & 女性 & 62 & 脳性小児麻㾝 & 短距離步行可 & 補装具制度による給付 & 標筙形は前にカバーが無いので怖い。 & $S$ ( $\mathrm{S}$ 社) \\
\hline 10 & 男性 & 56 & 関節脱白 & 短距離歩行可 & 不明 & ジョイスティックより運転しやすい。 & $S$ (S 社) \\
\hline 11 & 男性 & 69 & 左半身麻㾝 & 短距離歩行可 & 自費購入 & 簡単に手に入ったため。 & $S$ (E 社) \\
\hline 12 & 女性 & 73 & 右半身麻㾝 & 短距離步行可 & 介護保険による贷与 & 他に選択肢を知らなかった。 & $S$ (S 社) \\
\hline
\end{tabular}

歩行に関寸る A D L は、主に行動観察調查結果によって判断したものである。

表 2 主要なヒアリング項目

\begin{tabular}{|c|c|c|}
\hline $\begin{array}{l}\text { 使用する } \\
\text { ハンドル } \\
\text { 形電動車 } \\
\text { いすにっ } \\
\text { いて }\end{array}$ & \multicolumn{2}{|c|}{$\begin{array}{l}\text { 選択理由、使用機種、入手方法 } \\
\text { (制度利用の有無)、その他に } \\
\text { 使用している機器、以前に使用 } \\
\text { した機器、等 }\end{array}$} \\
\hline \multirow{3}{*}{$\begin{array}{l}\text { 外出時の } \\
\text { 使用につ } \\
\text { いて }\end{array}$} & $\begin{array}{l}\text { 使用域、 } \\
\text { 使用頻度、 } \\
\text { 使用目的 }\end{array}$ & $\begin{array}{l}\text { 電動車い寸使用の前 } \\
\text { 後における行動の変 } \\
\text { 化等 }\end{array}$ \\
\hline & $\begin{array}{l}\text { 建筑施設、 } \\
\text { 設備 }\end{array}$ & \multirow{2}{*}{$\begin{array}{l}\text { 利用する（しない） } \\
\text { 理由と利用上の問題 } \\
\text { 点等 }\end{array}$} \\
\hline & $\begin{array}{l}\text { 交通機関、 } \\
\text { 道路等 }\end{array}$ & \\
\hline $\begin{array}{l}\text { 在宅時に } \\
\text { つて }\end{array}$ & $\begin{array}{l}\text { 使用頻度、 } \\
\text { 保管場所 }\end{array}$ & $\begin{array}{l}\text { 保管場所等に関する } \\
\text { 問題点 }\end{array}$ \\
\hline
\end{tabular}

丧 3 行峌钼察調亘概要

\begin{tabular}{|c|c|c|c|c|c|}
\hline $\begin{array}{l}\text { 調查 } \\
\text { No. }\end{array}$ & $\begin{array}{c}\text { 対象者 } \\
\text { No. }\end{array}$ & 記録概要 & $\begin{array}{l}\text { 調査 } \\
\text { No. }\end{array}$ & \begin{tabular}{|c} 
対象者 \\
No.
\end{tabular} & 記録概要 \\
\hline 1 & (1) & バス、地下鉄利用〜自宅 & 9 & $\begin{array}{l}\text { (1), (5)、 } \\
\text { (6) }\end{array}$ & $\begin{array}{l}\text { 夜行バス利用〜会議出席、食事、 } \\
\text { 買物、地下鉄利用〜夜行バス、市 } \\
\text { バス利用 }\end{array}$ \\
\hline 2 & (1) & $\begin{array}{l}\text { 自宅〜自家用車、地下鉄利用～買 } \\
\text { 物、食事 }\end{array}$ & 10 & (7)、(8) & 職場〜買物〜自宅 \\
\hline 3 & (3) & 職場～買物～自宅 & 11 & (9) & 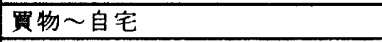 \\
\hline 4 & (2) & $\begin{array}{l}\text { 自宅〜買物、食事、カラオケ〜自 } \\
\text { 宅 }\end{array}$ & 12 & (4) & $\begin{array}{l}\text { 地下鉄利用〜会議出席〜地下鉄 } \\
\text { 利用〜食事 自宅 }\end{array}$ \\
\hline 5 & (1) & $\begin{array}{l}\text { 地下鉄、私鉄利用〜イベント見 } \\
\text { 学、食事、買物〜小型循環バス、 } \\
\text { 私鉄、地下鉄利用〜自宅 }\end{array}$ & 13 & (3) & 職場～買物、郵便局～自宅 \\
\hline 6 & (1) & 地下鉄利用～会議出席 & 14 & (2) & 自宅～買物、食事～自宅 \\
\hline 7 & (4) & 地下鉄利用～友人宅訪問 & 15 & (12) & パソコン教室〜買物〜自宅 \\
\hline 8 & (1)、(4) & $\begin{array}{l}\text { 地下鉄、私鉄利用～会議出席、食 } \\
\text { 事、賈物～私鉄、地下鉄利用 }\end{array}$ & 16 & (12) & トイレ内動作観察 \\
\hline
\end{tabular}




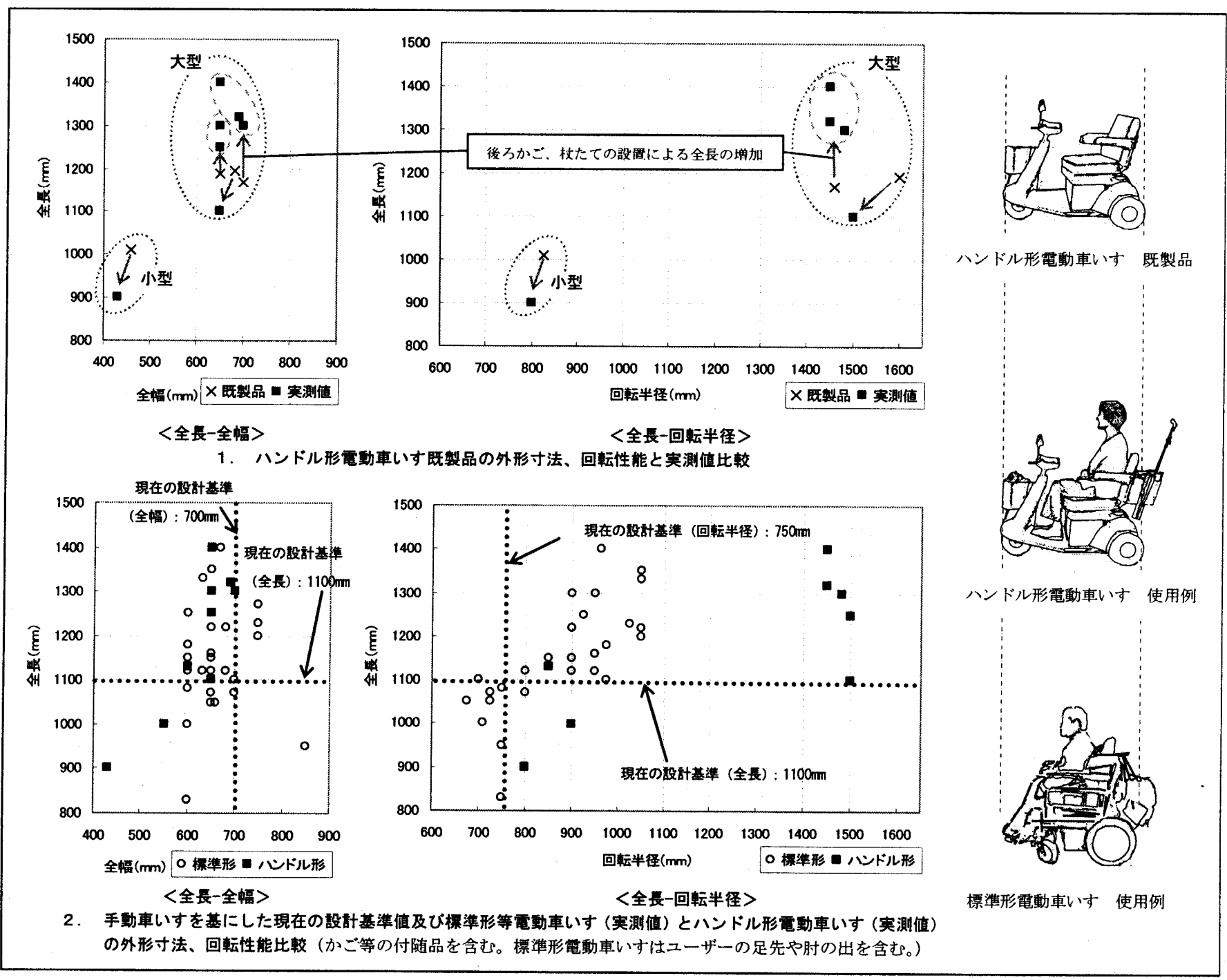

図 2 ハンドル形電動車いす、唄準形等電動車いす、手動車いすの機器寸法、性能比較 (「現在の設計基淮」として示したのは、手動車いすを基にして考えられた数值济6)である。)

ハンドル形電動車いすの選択理由では、脳性麻㾝等、手の吅緻性 が低いと考えられる人を中心に、標準形電動車いすのジョイスティ ックよりも運転しやすいことが多くあげられ、その他、入手しやす い、荷物を運べる、安定性がある等が選択理由となっている。 4.2 ハンドル形電動車いすの機器寸法、回転性能について

ハンドル形電動車いすは J I S 上、標淮形電動車いすと同じ規 格が適用され注4)、最大外形寸法は全長 $1200 \mathrm{~mm}$ 、全幅 $700 \mathrm{~mm}$ 、全高 $1090 \mathrm{~mm}$ である。しかし、前述したように両者は外形的に相違する (図 2 ) 他、方向転換する際の駆動方法も相違している注 5)。

したがって、施設、設備の利用に必要な通路幅員、面積等を考 える上で両者にどのような相違があるか、また、現在バリアフリ 一設計における車いす寸法の基準とされている、手動車いすユー ザーを基にした数值（以下、現在の設計基準値と記す）注6）と比較 して、どのような相違点があるかを把握するため、ヒアリング時 に機器全長、全幅、及び回転半径を実測した注 7 。

図 2 において、この実測值と、市販されているハンドル形電動 車い寸既製品の外形寸法、回転性能注8) との比較、及び前報文2) における標準形電動車いすユーザーを対象とした調查の実測結果
(ユーザーの身体を含めた全体についての寸法と回転半径実測結 果）とを比較した。また、図内に現在の設計基準值を付記した。 標準形等電動車い寸は、足先等ユーザーの身体の一部が機器よ りも外に出る（図 2 ）こと、また、頚剈道損傷や脳性麻㾝、筋ジス トロフィー等の全身性の重度肢体不自由者がユーザーである場合、 その身体状況に合わせて機器形状、機能を改変することから、前 報文2)における調查結果では、市販されている既製品の外形寸法と、 付随品やユーザーの体を入れた場合の外形寸法が相違していた。 しかし、図2に示すように、ハンドル形電動車いすの調査結果で は、ユーザーの体が機器より外に出ることはなく、ユーザーの身 体状況による外形寸法の変化が少ないため、市販されている既製 品と使用されている機器との相違は、主に荷物用のかご及び杖立 てを付随品として付ける場合の全長寸法の増大のみであると考え られる。

調查対象となったハンドル形電動車いすは、回転半径実測結果が 2 グループに分かれたため、これらを大型、小型として図 2 中に 示した ${ }^{\text {注 }}$ 。ハンドル形電動車いすの外形寸法計測結果には、全体 として標準形等電動車いすの計測結果との大きな差異は認めらな 
表 4 ハンドル形暉勤車いす使用による外出行勋の変化

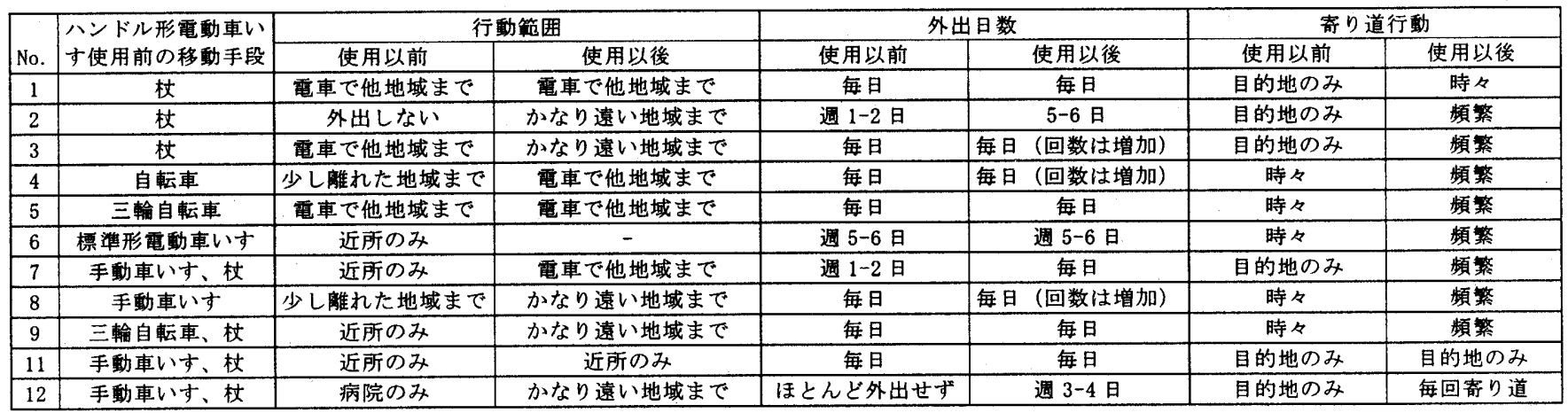

いが、一部小型タイプの数値は、全長全幅ともに標準形電動車い す計測結果の平均值より小さい。回転半径においては、大型では 標準形等電動車いすと比較して $50 \mathrm{~cm}$ 以上大きいものが多いが、小 型タイプの回転半径は、標準形等電動車いすの平均值に近い。

現在の設計基準值との比較においては、小型のハンドル形電動車 いすの場合、全長全幅共に現在の設計基淮値以下である。また、 大型の全長寸法及び大型小型両者の回転半径が、現在の設計基準 值より大きい。調查対象者が使用しているハンドル形電動車いす の計測寸法と現在の設計基隻値との差は、全長において最大 $30 \mathrm{~cm}$

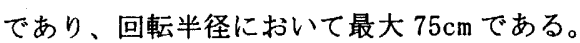

\section{3 電動車いす使用による外出行動の变化について}

手動車いすや杖等の、ユーザーの腕力や介助によって移動する移 動機器と比較して、電動車い寸の場合には個々人の体力差や日々の 体調、及び介助者の都合に左右されずに移動性が確保される。前報 文2)においては、標準形等電動車いすの使用がユーザーの生活一般 や外出行動にどのような影響を与えているかを調查した結果、「行 動範囲が拡大した」、「単独外出が可能になった」、「自由に外出で きるようになった」、「外出回数が増えた」等の変化が認められた。

今回の調査においては、ハンドル形電動車いすューザーに対し、 その使用前後における外出日数、外出範囲、寄り道行動の頻度の変 化についてのヒアリングを行った。その結果、表 4 に示すように、 電動車い寸使用以前の外出籁囲が限られていた対象者は広がり、外 出日数が少なかった対象者は増加していた。また、寄り道行動が增 加し、以前は外出目的を済ませるだけであった対象者が、買物等の
奇り道を頻繁に行うようになっており、全般的に、電動車いす使用 が調查対象者の外出範囲、回数、内容を活性化させている傾向が明 確に表れていた。

注目すべきヒアリング結果として、例えばNo, 7 の対象者（外出 日数 1,2 日/週一毎日に增加）の、「杖では長い距離を歩くことがで きなかったのであまり外出しなかったが、頻繁に外出できるように なった」という内容、No. 12 の対象者（ほとんど外出せず $\rightarrow 3,4$ 日／ 週に増加）の、「手動車いすでは介助が必要で気兼ねした」等があ る。これらは、以前の消極的な外出行動の原因について述心゙、生活 が活性化された喜びを表す内容であり、対象者 12 人中 6 人に同様 の内容が記録された。

4.4 機器使用、施設利用の状況、及ひ問題点について

\section{4.1 機器使用、施設利用の状況}

ハンドル形電動車い寸ユーザーによる典型的な地域施設利用の あり方と、利用状況を変化させる要因について、I C F モデル（W HOによる「生活機能・障害・健康の国際分類」）注 10) の概念を参 考に図 3 のように整理した。

ハンドル形電動車いすによる施設利用状況の特徴として、他の車 いすと相違し、二つの傾向があることがあげられる。ハンドル形電 動車いすを建築施設間の移動に使用し駐輪場等に駐車するという、 自転車の用途に近い場合（図 3 右写真）と、施設内もハンドル形電 動車いすによって移動するという、他の車いすと同じ使用形態（図 3 左写真) である。

地域施設の利用状況を変化させる最も支配的な要因は、歩行困難

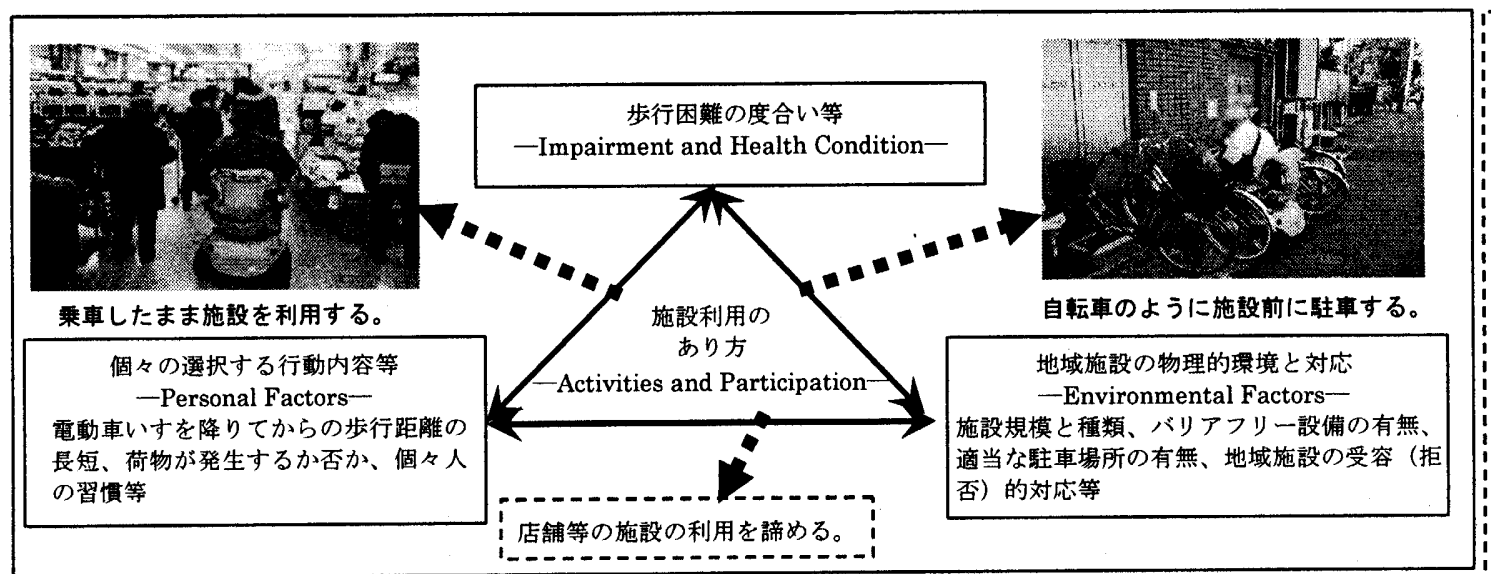

<事例 1>

No.2のユーザ 一は、ごく短距離 ならば杖で歩け る。奥さんも足が 弱っている。3 日 に一度、多量の買 物をするスーパー は、通路が狭く 中までハンドル形 で入れない。店の 前に駐車して、杖 とカートで買物を するが、できれば ハンドル形電動車 いすに乗ったまま 利用したい。

图 3 ハンドル形車動車いすユーザーによる施設利用状況の多様性と要因、及び施設利用状況の事例 (要因等の分類概念については 2001 年版 ICF (WHO) * 10 ) を参考にした。) 


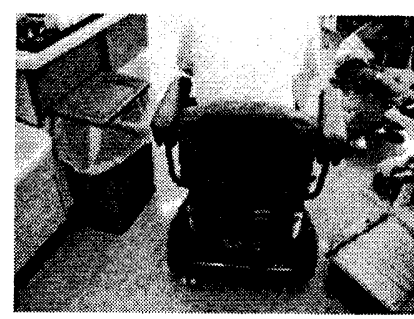

图 4 通路に贯かれる障害物

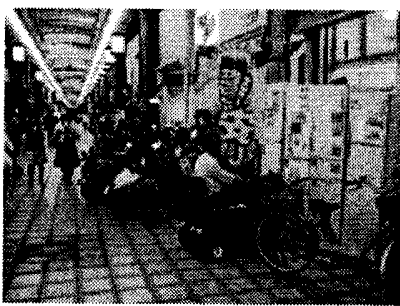

図 5 駐車場所がないた め路上に俥める
度であり、自転車的な使用傾向が強いユーザーは比較的歩行能力 が高く、大規模な施設を除いて、屋内では基本的にハンドル形電 動車いすを使用していない（ヒアリング No. 3、10）。一方、車い すとしての使用傾向が強いユーザーは、歩行がまったく不可能あ るいは非常に困難であり、店舗等の内部や交通機関も、できるだ けハンドル形電動車いすによって利用している（ヒアリング №. $1 、 4 、 5 、 6 、 8 、 12)$ 。

しかし、このようなハンドル形電動車いすによる施設利用状況 の変化は、同一ユーザーの施設利用行動ごとにもあり（行動観察 調查 No. $3 、 4 、 5 、 9 、 10)$ 、歩行困難度のみで一律に決定され ない。他に、個々の選択する行動内容の身体的負荷（電動車いす を降りてからの歩行距離の長短、荷物が発生するか否か等) や習 慣等の個人的要因、建築設備、交通機関の物理的環境と対応（施 設規模、バリアフリー設備の有無、適当な駐車場所の有無、地域 施設側の受容と拒否等) 等の環境的要因が認められ、これらが身 体的要因と相互に影響し合って、施設利用状況を変化させている。

\section{4.2 施設規模と施設種類による問題点の相違}

以上のように、ハンドル形電動車いすによる地域施設利用上の問題 点には、施設内をハンドル形電動車いすのまま利用したいができない 場合、及び、施設入口付近に駐車したいが適当な場所がない場合があ り、歩行がまったく不可能な場合を除き、ユーザーの歩行困難度以 外の個人的環境的要因によっても、どちらの改善ニーズが高いかが 相違してくる。つまり、施設規模と種類によって問題の重点が変わる と思われ、買物等、荷物の発生が確実であるほど、また、施設規模
が大きく歩行距離が長くなるほど、屋内までハンドル形電動車い すで入っていくニーズが高く、大規模でなく荷物の発生も少ない と考えられる施設に関しては、比較的駐車場所に対するニーズが 高いと考えられる。

ヒアリング及び行動観察調查結果では、前者の現状として、出入り 口扉が自力で開けられない、内部通路が狭い、通路に障害物が置かれ ている（図 4) 等の問題が一部にあることが認められた。この場合、 個々のユーザーが、通行人や店員に介助を依頼したり、スポット的に 歩行する等の対応をして施設を利用したり、あるいは、利用を諦めた りしており、利用されている店舗内では、販売棚に接触する、通路に 置かれた商品のために通過できない等の状況がある。また、後者の現 状としては、自転車の駐輪問題と同様、現在十分な対策は取られて いないため、ユーザーは路上（図 5 ) や自転車置場、屋内の空きスペ 一ス等に停めて利用したり、施設の利用を諦めたりしており、利用さ れている施設では自転車が多くて停められない、屋内への経路に段差 がある等の問題がある。

じたがって、大規模な施設及び物品販売施設等の荷物の発生が予測 される所では、施設内をハンドル形電動車いすで利用するための配 慮が必要であり、他の車いすに対する配慮に準じた上で、現在の八 ンドル形電動車いすの機器性能（回転半径が大きい。4.2参照） を考虑し、通路幅員、販売棚間隔等をより広くし、障害物を置かな い等の配慮が望ましいと考えられ、小規模な施設または荷物の発生が 予測されない施設では、出入口付近（建物の出入口から遠い場所や 階段のある経路は避ける）に適当な駐車場所を確保し、動線上の適 所に手摺やベンチ等を設置する等の配虑が必要と考えられる。

4.4 .3 住宅の問題（在宅時の使用について）

在宅時の使用においては、標準形等の電動車いす調査結果注 (11) と相違して、自宅内部も全てハンドル形電動車いすで移動してい る事例は少なく、調查対象者 12 人中、過去に使用していた人が 1 名のみである。他のユーザーは住宅の内外にハンドル形電動車い すを停め、居室内の移動には使用していない。

保管場所の問題として、戸建て住宅の場合はガレージ（図 6 左下

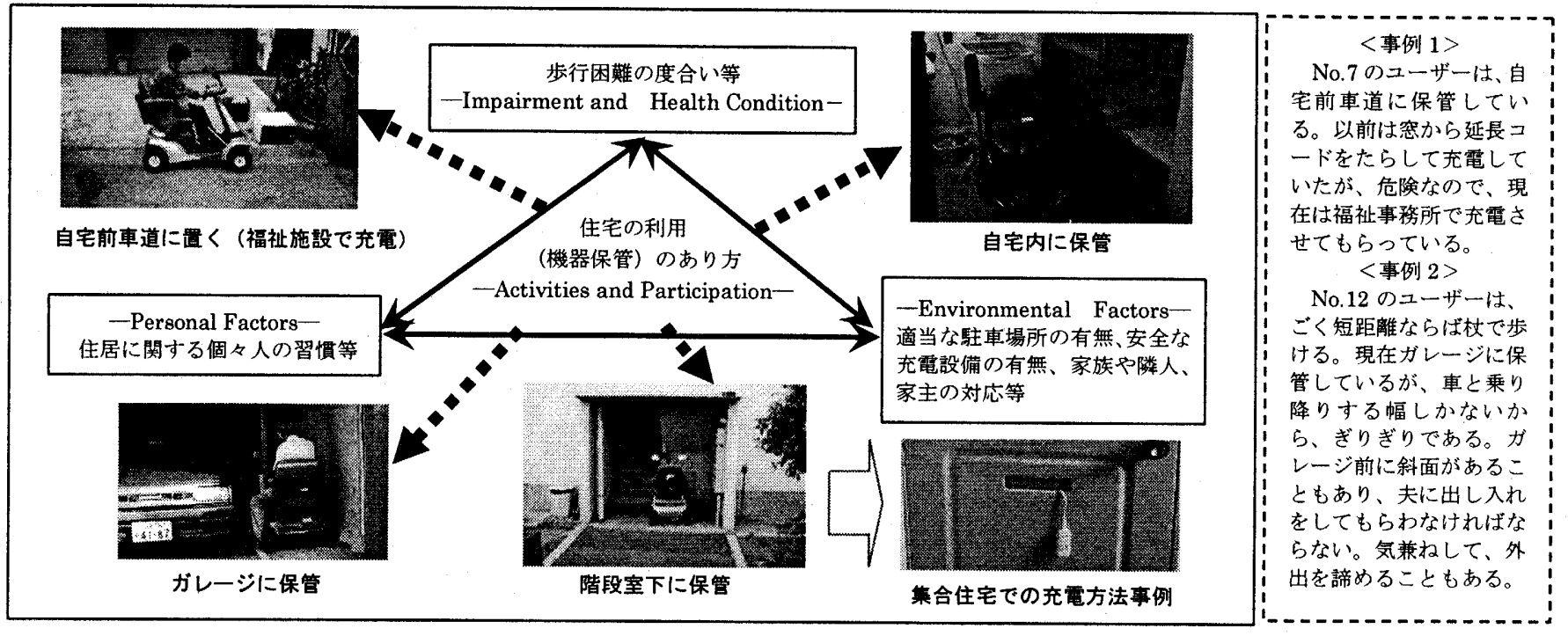

図 6 ハンドル形電動車いすによる住宅の利用（機器保管）のあり方の多様性と要因、及び住宅利用（機器保管）の事例 


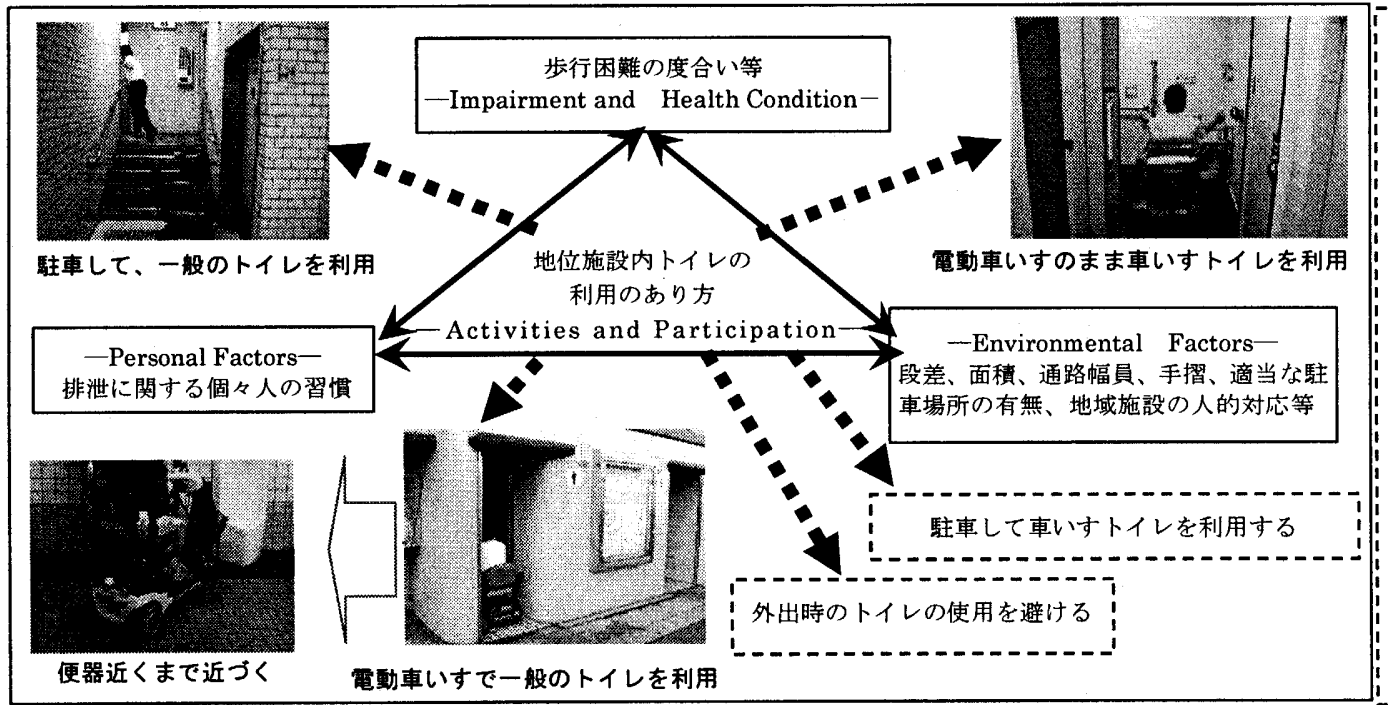

$<$ 事例 $1>$

No.5のニーザーは、短距離 なら歩けるが、倒れると起き 上がれない。車い寸トイレは 奥まった場所にあると利用し ない。広い場所からすぐ入れ るところは利用する。内部で 回転できないので声をかけな がらバックで出る。現在の八 ンドル形に乗り換えてから普 通用のトイレの中（個室の手 前まで）へ入れるようになつ た。

\section{<事例 2>}

No.6 のユーザーは、歩けな いので、ハンドル形で車いす トイレまで入って利用する。 車いすトイレは「んへ入れる」 だけでなく、便器へ横付けで きるようにしてほしい。また、 中で回転できないので困る。

図 7 ハンドル形電動車いすによる地域施設内トイレ利用のあり方の多样性と要因、及び地域施設内トイレの利用事例

写真)、軒下等にハンドル形電動車いすを保管しているが、集合住 宅の場合は適当な場所や設備がない事例が多く、住宅外の保管では 車道 (図 6 左上写真)、共用廊下、階段室下（図 6 中央下写真）等 があり、住宅内に保管している事例では、車い寸住宅のトイレ内 (図 6 右上写真)、居室内（休にマット敷）がある。

4.4.4 地域施設内におけるトイレの問題

車いすトイレに関するヒアリング（対象者 12 人）項目に対し、「一 般のトイレが入れる状況であれば車いすトイレには入らない」とい う人が 6 人、「車いすトイレは使わない」という人が 3 人存在し、 車いすトイレを利用するユーザーの方が少ないという結果となっ た。行動観察調查においても、トイレ前に駐車して、あるいは、便 器近くまでハンドル形電動車いすで入り、一般用トイレを利用する 行動（図 7 中央下及び左下写真）がみられた。一方では、ハンドル 形電動車いすのまま車いすトイレを利用する事例（図 7 右上写真） もある。図 7 に示したような、複数の要因が相互に影響して、行動 を変化させていると考えられる。

車いすトイレの場合、ブース内面積の不足が問題である。回転 半径が約 1,500mm (図 2 参照) であるハンドル形電動車いす (大型) の場合、内部で回転できないために前進で入り後進で出なければ ならない。また、一般用トイレを使用する場合には、段差（図 7
左上写真）があったり、出入り口の幅員が狭かったりして、歩行 可能な距離まで近づけないという問題がある。また、車いす用一 般用共に、通路の奥にある等、トイレへのアクセスが難しく、ま た、ハンドル形電動車いすを停めておく場所や杖を立てかける場 所がない等の問題がある。

\section{4.5 交通機関の問題}

金らの調查文9)によれば、機器製造メーカーにおいては、ハンド ル形電動車い寸のまま交通機関を利用するという想定はされてい なかった。また、国土交通省の交通バリアフリー技術規格調查研 究報告書文 ${ }^{10)}$ にお打対応方針の検討では、基本的に交通機関の 利用を認めるハンドル形電動車い寸を、回転性能等、機器の改善 がなされるまでは、補装具注 12) として判定を受けた障害者のもの に限って当面の対策が考えられている社 13)。

今回の調査では、対象者 12 人のうち 5 人（その内、補装具制度 利用 4 人) のユーザーが、何らかの交通機関をハンドル形電動車 いすで利用した経験があり、鉄道に関しては回転半径の大きい比 較的大型のものを使用しているユーザーの利用も認められた。ま た、ハンドル形電動車いすで利用しない場合には、駅で降りて杖 等により歩行して利用する、介助者を確保して手動車いすで利用 する、利用を諦める、拒否的対応の交通機関に対して交渉する等

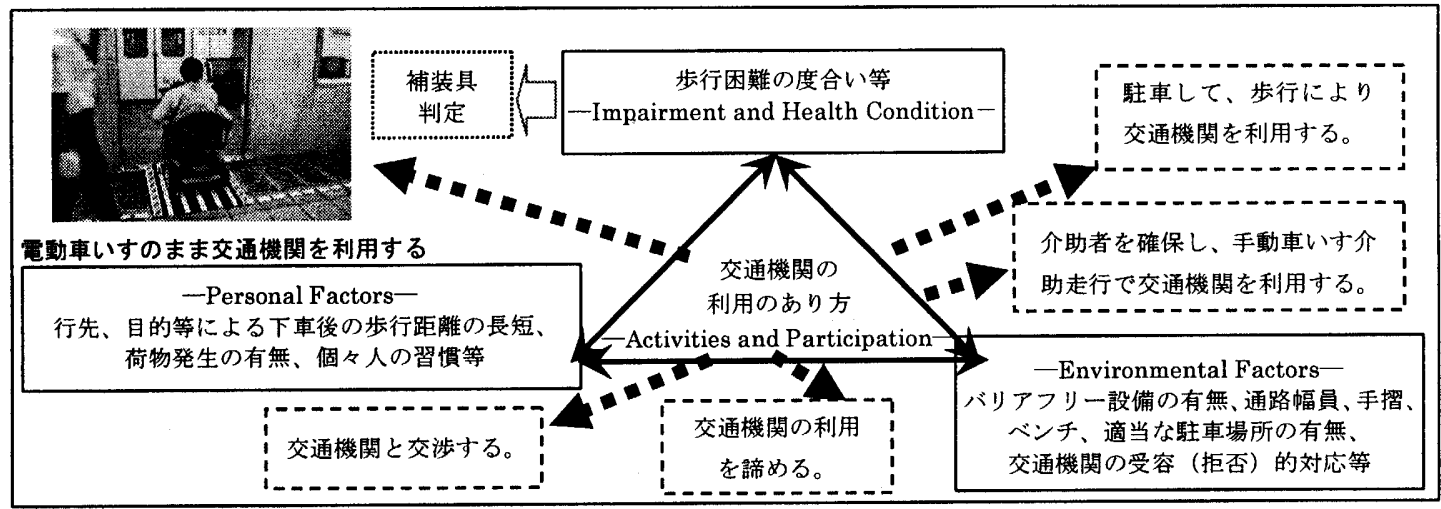

$<$ 事例 1>

No.7のユーザーは、地下 ! 鉄や JR、私鉄を、ハンド ル形電動車いすで利用し ているが、EVのない駅を！ 利用する時や、ハンドル形 で利用できない場所へ行 く時には、介助者を確保し て、手動車いすで出かけ る。

以前後乃かごをつけて いたら地下鉄の E Vに乗 れれ゙、駐車して杖で乗った が、非常に疲れて苦労し た。現在は外した。

图 8 ハンドル形電動車いすによる交通嘰関利用のあり方の多様性と要因、及び交通機関利用の事例 


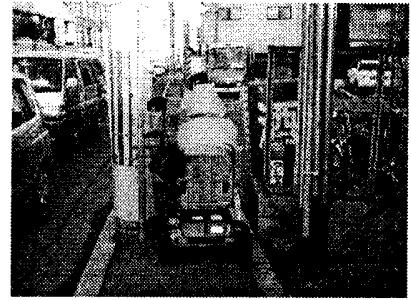

図 9 歩道の偪冒不足と障害物
图 10 歩道の横断勾配による

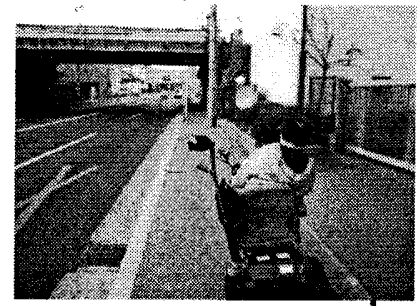

の行動が認められた（図 8 )。

また、このような交通機関の利用のあり方と行動は、同一のユ 一ザーでも一定であるとは限らず、図 8 に示すように、ユーザー の身体的要因の他、行先、目的による交通機関を降りた後の歩行 距離の差、荷物発生の有無、その他個々人の習慣等個人的要因、 また、エレベータ等バリアフリー設備の有無、適当な駐車場所、 ベンチ、手摺等の有無、交通機関側の受容（拒否）的対応等環境 的要因によって変化すると考えられる。

前述の国土交通省による当面の対応方針（文 10 参照）の場合、 障害者の補装具としての判定を利用者の条件としているが、補装 具判定は、歩行困難度等身体的要因の目安とはなるものの、他の 要因（個人的要因、環境的要因）を含めた相互関係全体の目安と はならない(図 8)。

\section{4.6 道路の問題}

道路交通法上、電動車い寸は歩行者と同様の扱いであるため、 歩道を走行することになる。ハンドル形電動車いすユーザーへの ヒアリング及び行動観察調査の結果、道路に関しては、段差、傾

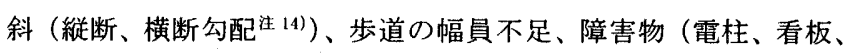
駐輪駐車等)、舗装等、おおよそ他の車いすと同様の問題が認めら れた（図 9、10）。相違点としては、機器の構造、操舵方法、性能 から、他の車いすと比較して横断勾配に強いこと、手動車いすと 比較して繸断勾配に強いこと等の点があげられる。

歩道の問題に対処するには、車道を走行する、問題のある箇所 を迁回する、通行人等に障害物の除去を依頼する、ガイドヘルパ 一注 15) に誘導を依頼する等の行動が認められた。

\section{5 結論}

ハンドル形電動車いすユーザーのヒアリング及び実測調查、行 動観察調查とその分析から、導き出される点を以下に述べる。 5.1 ハンドル形電動車いすユーザーの生活の変化と機器特性 1）ユーザーの体力や介助者の都合によって移動範囲が制限され る移動機器（杖、手動車いす等）から電動車いす使用に切り替え ることにより、ユーザーの外出行動が活性化されている。今後、 歩行困難のある障害者、高龄者が、電動車いすを使用した場合、 従来より広範囲の積極的な地域施設利用が想定される。

2）調查対象となったハンドル形電動車いすを、大型のものと小 型のものに分類した。大型のものの回転半径は標準形等電動車い す実測平均值より $50 \mathrm{~cm}$ 以上大きいものが多いが、外形寸法(全長、 全幅)は、かご等の付随品を設置した時の全長寸法の增大を除き、 標準形等電動車いすと大きく変わらない。また、小型のハンドル
形電動車いすの外形寸法は、現在の設計基淮值注 6) 以下であり、回 転半径は標準形等電動車いす実測結果の平均値に近い。

5.2 ハンドル形電動車いすューザーの行動の多様性と要因、地 域施設改善策

1） ハンドル形電動車いすによる施設利用状況は、自転車的に施 設入口付近へ停め、杖等により歩行して施設内を移動する場合か ら、他の車いす同様、電動車いすのまま施設内を移動する場合な どまで、多様性がある。また、同一のユーザーにおいても、歩行 困難度等身体的要因のほか、個々の行動内容の身体的負荷や習慣 等の個人的要因と、施設側の物理的環境と対芯等の環境的要因と が相互に影響し、行動の単位ごとに変化する。

2）したがって、ハンドル形電動車いすに対応する地域施設の改 善策を検討するにあたっては、施設規模や種類によって整備の重 点を变えるのが、より効果的である。つまり、大規模な物品販売 施設等では、段差解消等、他の車いすに対応する改善点に準じた 上で、販売棚間隔等通路幅員をより広くし拄 16 、そ施設をハンド ル形電動車いすで利用できる条件を確保すること（以後、利用条 件整備と記す）に改善の重点を置く。また、小規模で荷物の発生 も考えられない施設においては、適当な駐車場所の設置と、駐車 場所から施設内までの安全なアクセス経路、休秝場所の設置等 (以 後、駐車及び歩行条件整備と記す）に改善の重点を置くことが考 えられる。

3）住宅においては、駐車及び歩行条件整備に加え、駐車場所に おける充電設備の計画が必要である。特に集合住宅では、計画時 にこれらを考慮しておくことで、本来の共有スペースや住居内居 室、廊下等の用途が確保され、住居の安全性が保たれる。

4）地域施設内トイレにおいては、利用条件、駐車及び歩行条件 整備の両者とも、一般用トイレへのニーズが高いことが特徴であ る。車いすトイレの場合には、ハンドル形電動車いすに乗車した ままの内部利用には、面積不足で転回できない等の問題があり、 一部の歩行不可能なユーザーにとって、扉の開け閉めや手洗い等 の設備使用が困難な状況となっている。

5）交通機関に関しては、機器開発及び施設両者の側から利用条 件整備が目指されているが、本調查の結果では、さらに、駐車及 び歩行条件整備を同時に行い、様々な利用のあり方に対応可能と することが望ましいと考えられる。また、障害者の補装具か否か といった分類での利用者限定に関しては、本研究における地域施 設利用状況の変化要因分析という観点からは、有効性に限界があ ると推測される注 17)。

なお、本報の調查対象者は、ハンドル形電動車いすユーザーの 中でも、相対的に歩行困難度が大きい層である。比較的歩行が困 難でない層は、ハンドル形電動車いすを駐車し、地域施設内を歩 行して利用する率が高いと考えられるが、その場合には駐車及び 歩行条件整備の必要性がより高まることになる。これについては 今後の課題としたい。

謝 辞

調查にご協力頂いた、ハンドル形電動車いすのユーザーの方々に 
厚くお礼申し上げます。調査結果をまとめるにあたって、大阪市援 助技術研究室の方々に頂いた助言を参考にさせて頂きました。また、 調查にあたって西村研二氏（当時大阪大学大学院生）に協力を頂き ました。記してお礼申し上げます。

【注】

1）本論文においては、車いす、杖、歩行器等の歩行機能を補助する機器を 指すものとする。

2）電動車い寸安全普及協会に上れば、同協会加入会員からの提出データに 上る出荷台数累計（2003年度）は、ジョイスティック形 95,854台、ハン ドル形（電動カート、シニアカー等と呼ばれる）296, 094台である。文 4 参 照。

3）本論文においては、地域住民が日常生活で利用する生活関連施設（行政 管理施設、医療施設、社会福祉施設、商業施設、レジャ一施設等）及び住 宅、交通機関、道路を含むものとする。

4）JIS規格による電動車いす形式分類は以下の通りである。文 5 参照。

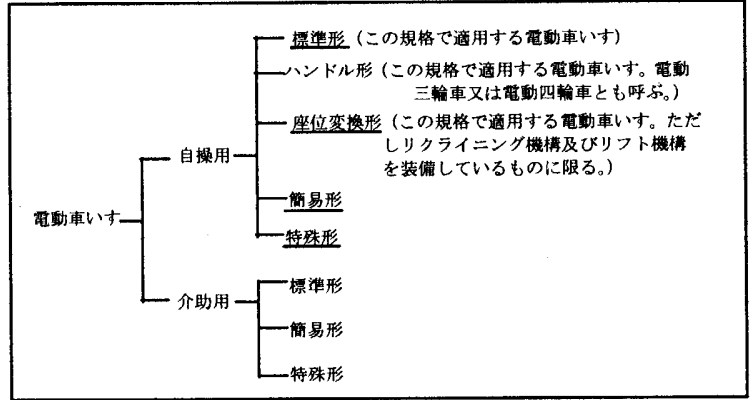

JIS T9203「附属書1（規定）電動車い寸形式分類」を基に作成。

（下線は前報（文2）における調查の箅囲を示す）

5) 現在の一般的機器性能としては、標準形等の電動車いすが左右の後輸の 回転数の差によって方向転換を行うのに対し、ハンドル形電動車いすは ハンドルによる前輸の操舵で方向を転換する。したがって、回転軸は車 体の外になり、回転に要するスペースが大きい。

6)『コンパクト建筑資料集成 バリアフリー』（文 6 ）中、車いすに関する 設計基準值として最も多く揭载されている数值を使用した。文 2 参照。

7）調查対象者が実際に使用している電動車い寸に、運転時の自然な姿勢で 乗り、静止した状態で、横、正面、後方の写真記録をすると同時に、機器

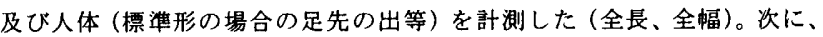
その静止時の床の位圈を記録し（ビニールテープ等使用）、180 度向きを 変えて頂いた。この時、必要となるスペースの長径側寸法を計測し、ハン ドル形電動車いすの既製品情報と比較するため、それぞれ $1 / 2$ 倍の数值を 使用した (回転半径)。

8）財団法人テクノエイド協会ホームページ福祉用具情報システムにおける、 ハンドル形電動車いすの外形寸法、性能の数值を使用した。文 7 参照。

9）本調查の計測結果として、回転半径の值が 2 グループに分かれたことに よるものであり、メーカーが基準を設けているのではない。

10) Interaction of Concepts ICF 2001、文 8 参照。

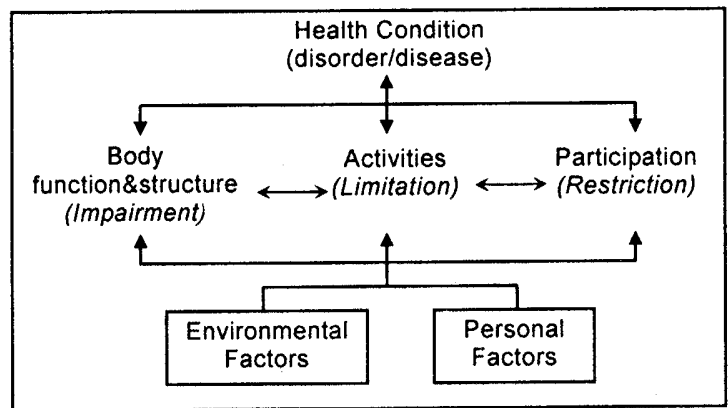

ICF : International Classification of Functioning, Disability, and Health/WHOによる「生活機能・障害・健康の国際分類」
11）標準形等の電動車いすユーザーの調查結果では、在宅時の居室内移動 においてもすべて電動車いすを使用している人の率が高い結果となった (アンケート対象者 65 人中 21 人、32.3\%)。文 2 参照。

12）補装具とは、身体障害者福祉法等において、身体障害者(坚)のために、 失われた身体機能を補完・代僙し、身体に装着（装用）して常用するも の又は作業用に使用する用具とされ、交付を受けるには、身体障害者手 帳を所持し、原則的に、それぞれの補装具に定められた障害程度に該当 寸るという更生相談所の判定が必要である。

13）・だし、交通機関によっては独自に判断し、ハンドル形電動車いすで の利用を認めている。

14）道路進行方向に傾いた傾斜を繸断勾配、進行方向に対し直角に傾く傾 斜を横断勾配という。車いす走行にとって横断勾配は、低い方へ流され る、予期しない動きをもたらす等の影響がある。文 11,12 参照。

15）障害者の外出時の介助を行うへルパー。

16）図 2 に示したように、ハンドル形電動車いすの全幅は、他の車いすと 変わらないため、通路に直進して進入し、そのまま通り拔ける場合には、 特別広くする必要はないと考えられる。しかし、回転半径には大きな差 があるため、方向転換しながら通路へ侵入する場合には、他の車いすよ り広い問口が必要であり、通り拔けできない通路での方向反転には、手 動車い寸より約 $1,500 \mathrm{~mm}$ 広いスペースが必要であると考えられる。

17）我が国の障害者福祉制度では、補装具判定の方法を含め、障害を主に 医学的側面から認定するため、移動機器ユーザーの生活環境整備を考え る場合の指標として、障害者という概念が有効である限界については、 常に意識すべきである。福祉制度上の障害者あるいは高龉者という概念 は、男女別の上うに明確な分岥のある属性を持たず、年龄や歩行能力等 の評価軸上に、連続して散らばる属性を持つ人々を便宜的に線引きし、 分類している。現実には、I C F モデル（注 10 参照）のように、個人的 環境的要因（背景因子）が影響し、身体的要因（身体機能及び構造、健 康状態）の相互関係において人間の行動様態をつくり上げるため、制度 上の障害者、高齢者という分類を使用した施設利用の限定は、合理的限 界があると考えられる。

【参考文献】

1）中島佐智子，柏原士郎，吉村英祐，横田隆司，飯田匡，西村研二：ハン ドル形電動車い寸による施設利用上の問題点とその改善方策についてー 電動車いすの使用実態調查に基づくバリアフリー設計に関する研究一, 地域施設計画研究, Vol. 22, pp. 209-216, 2004.7

2）中島佐智子, 柏原士郎, 吉村英祐, 横田隆司, 飯田匡：電動車い寸ユ一 ザーを対象とした使用実態調查一電動車いすユーザーに対応寸る生活環 境に関する研究一, 日本建築学会計画系論文集, No. 585, pp. 55-62, 2004. 11

3）淦端光雄，北川博巳：高齢者のモビリティ確保のための電動車いす利用 に関する研究, 土木計画学研究・講演集, Vol. 26 (CD-ROM みみ), 2002

4) 電動車いす安全普及協会: 電動車いす出荷台数/累計出荷台数 [平成 15 年度], http://www. den-ankyo. org/,2005.1

5）財団法人日本規格協会編集：JIS ハンドブック 高路者・障害者一アク セシブル・デザイン-, 財団法人日本規格協会，2004

6）日本建築学会編：コンパクト建築资料集成バリアフリー，丸善，2002

7）盰団法人テクノエイド協会ホームページURL：

http://www. techno-aids. or. jp/

8) ICF HomePage URL : http://www3, who. int/icf/

9）金利昭、高橾幸平，山田稳：電動三輸車の位圈つけと共存性に関する研 究，国際交通安全学会誌，Vol.26，№.1，pp. 48-56，2000.12

10）交通バリアフリー技術規格調查研究委員会：交通バリアフリー技術規 格調查研究報告書，国土交通省総合政策局交通消費者行政課，2003.3

11）彦坂涉, 田中直人：片斜面における手動車いす使用者の走行状態の評 価に関する実験的研究 車いすの走行速度・軌跡と走行の困難さの評価， 日本建筑学会計画系論文集, No. 570, pp. 57-63，2003.8

12）中川伸一, 栗山清, 小笠原章, 横山哲：「人にやさしい道路」を目指 して 步道横断勾配が車椅子の挙動に及ぼ影響, 土木学会土木計画学研 究・論文集, No. 12, pp. 775-786, 1995.8

（2005年 2 月 10 日原稿受理， 2005 年 8 月 30 日採用決定） 